\title{
Serum thyroid stimulating hormone and antioxidant status in patients with suspected thyroid dysfunction
}

\begin{abstract}
The incidence of thyroid disorders is reported in significant numbers globally. Patients referred for thyroid function tests to the Nuclear Medicine unit, University of Peradeniya, Sri Lanka were assessed for antioxidant status in addition to routine investigations. Among the patients investigated $41.9 \%$ had enlarged thyroid glands while others $(58.1 \%)$ did not show any thyroid enlargement. Majority $(79.5 \%)$ of the patients with enlarged thyroid, had multi nodular goiter, while only $12.8 \%$ had diffused enlargement and $7.7 \%$ had solitary thyroid nodules.

Ninety three subjects formed the study group and their mean Thyroid stimulating hormone (TSH) concentration was $5.4 \pm 12.3 \mathrm{mU} / \mathrm{L}$ with a range from 0.1 to $58.0 \mathrm{mU} / \mathrm{L}$. Their mean serum Total antioxidant capacity (TAC) was $719.1 \pm 164.5 \mu \mathrm{mol} / \mathrm{L}$ and mean serum Protein thiol concentration was $517.7 \pm 89.8 \mu \mathrm{mol} / \mathrm{L}$. Age had a significant positive correlation with $\mathrm{TAC}(\mathrm{r}=0.268, \mathrm{P}=0.009)$, and a significant negative correlation with protein thiol $(\mathrm{r}=-0.481, \mathrm{P}<0.001)$. BMI of the patients increased significantly with age. Among the patients, $9(9.7 \%)$ were hyperthyroid, $68(73.1 \%)$ were euthyroid while $16(17.2 \%)$ were hypothyroid. There was a significant positive correlation between TSH and TAC $(r=0.526, \mathrm{P}=0.036)$ in hypothyroid patients which had not been reported previously. The mean serum TAC in males $(928.7 \pm 60.4 \mu \mathrm{mol} / \mathrm{L})$ was significantly higher than that of females $(699.4 \pm 150.5 \mu \mathrm{mol} / \mathrm{L})(\mathrm{P}=0.006)$. Similarly, mean serum protein thiol concentration of males $(570.7 \pm 23.6 \mu \mathrm{mol} / \mathrm{L})$ was significantly higher than that of females $(512.7 \pm 90.0 \mu \mathrm{mol} / \mathrm{L})(\mathrm{P}=0.049)$. No significant differences in TAC and protein thiol concentration were evident among euthyroid, hyperthyroid and hypothyroid patients which suggest that the antioxidant status does not differ among the different categories of patients investigated.
\end{abstract}

Keywords: thyroid dysfunction, total antioxidant capacity, thyroid stimulating hormone, protein thiol, euthyroi
Volume I Issue I - 2014

\author{
Sivakanesan R,' Wickramarathne AMSM, ,',2 \\ Nanayakkara DKK ${ }^{3}$ \\ 'Department of Biochemistry, University of Peradeniya, Sri \\ Lanka \\ ${ }^{2}$ Postgraduate Institute of Science, University of Peradeniya, Sri \\ Lanka \\ ${ }^{3}$ Nuclear Medicine Unit, University of Peradeniya, Sri Lanka
}

Correspondence: R Sivakanesan, Department of Biochemistry, University of Peradeniya, SriLanka, Tel + 94-8I-2396323, Fax + 94-8I-2389I06, Email rsiva@pdn.ac.lk

Received: October 29, 2014 | Published: December 03, 2014
Abbreviations: TSH, thyroid stimulating hormone; TAC, total antioxidant capacity; ROS, reactive oxygen species; $\mathrm{SH}$, thiol groups; TAC, total antioxidant capacity; FRAP, the ferric reducing ability of plasma; IRMA, immunoradiometric assay; NAFLD, non-alcoholic fatty liver disease; FT4, free thyroxine

\section{Introduction}

Thyroid disorders are being increasingly reported in world literature. Thyroid function has been reported to be associated with non-alcoholic fatty liver disease (NAFLD) in euthyroid subjects where the study revealed that subjects with NAFLD had significantly higher thyroid-stimulating hormone (TSH) and lower free thyroxine (FT4) levels than those without NAFLD. ${ }^{1}$ The Universal Salt Iodization program in mainland China reduced the prevalence of goiter by almost half after 1996. However, subgroup analysis suggested that both insufficient and excess iodine may be associated with goiter. The prevalence of goiter and thyroid nodules increased significantly after 2002, suggesting a risk of excessive iodine intake. ${ }^{2}$ Anupama Dave et al., ${ }^{3}$ reported that high risk screening is mandatory in early pregnancy since maternal subclinical hypothyroidism during pregnancy is associated with various adverse outcomes.

Thyroid hormones are modulators of basal metabolic state, protein degradation and oxidative metabolism. Hyper secretion of thyroid hormone has been shown to increase the production of reactive oxygen species (ROS) which results in oxidative stress. ${ }^{4-6}$ Oxidative stress is a general term used to describe a state of damage caused by ROS. ROS have a high reactivity potential, therefore they are toxic and can lead to oxidative damage in cellular macromolecules such as proteins, lipids and DNA. Thyroid dysfunctions can cause changes in antioxidant levels which could result in significant organ dysfunction. Oxidative stress has been associated with a number of human diseases, such as cancer, coronary heart disease, arthritis, diabetes, cataract and degenerative disease. Therefore maintenance of adequate antioxidant levels is essential to prevent or even manage a great number of disease conditions. ${ }^{7}$ Determination of the oxidative stress of a person is useful to assess the risk of a disease and to understand the disorders occurring as a result of oxidative stress. ${ }^{8}$

The main elements determining the antioxidant Plasma antioxidant include serum uric acid concentration and the content of SH groups in plasma proteins. The thiol groups $(\mathrm{SH})$ in plasma proteins, are sensitive to free radicals. As - $\mathrm{SH}$ groups are easily mended in the reduction process, protein thiols have a protective function for other molecules. So any reduction in the content of protein thiols can be used to evaluate the intensity of free radical processes. ${ }^{9}$

Some low molecular weight compounds in plasma such as Vitamin C, Vitamin E, bilirubin and uric acid also act as antioxidants. The reducing power of all these plasma constituents with both hydrophilic and hydrophobic character estimated all together is the Total Antioxidant Capacity (TAC). The ferric reducing ability of plasma (FRAP) established by Benzie et al., ${ }^{10}$ is a convenient method 
of measuring the TAC, as it is inexpensive, reagents are simple to prepare, results are highly reproducible, and the procedure is straight forward and speedy.

In Sri Lanka studies on thyroid functions have been carried out in school children and pregnant women in recent times. The problem of goire in Sri Lanka was reported as far back as $1967 .{ }^{11}$ In a study conducted with 59,158 children from 87 schools in 17 out of 24 districts in Sri Lanka for goiter, the overall prevalence rate was $18.8 \%$ (23.2\% for girls and $14.0 \%$ for boys). Prevalence in districts varied from $30.2 \%$ in Kalutara (coastal area) to $6.5 \%$ in Matale (hilly area). ${ }^{12}$ Premawardhana et al. ${ }^{13}$ showed evidence for a high prevalence of anti-thyroglobulin antibodies in Sri Lankan school girls and postulated it to be due to excessive iodination of thyroglobulin resulting in an increase of immunogenicity. The prevalence of antithyroglobulin antibodies and thyroid peroxidase antibody in pregnant women showed a progressive decline compared to non-pregnant controls throughout gestation becoming undetectable in the third trimester which indicated an immunosuppressive effect of pregnancy in a population in whom high thyroid autoantibody titers may have resulted from a recent salt iodization program. ${ }^{14}$ However no studies have been conducted on the antioxidant status of patients with thyroid disorders despite the fact that the thyroid hormones have an influence on metabolic activities.

The present study was conducted with the objective of (1) assessing the thyroid function based on serum TSH concentration and (2) understanding the relationship between serum TSH and serum antioxidant concentrations in patients with suspected thyroid dysfunction who were currently not on treatment.

\section{Materials and methods}

Ninety three consecutive patients referred to the Nuclear Medicine unit, University of Peradeniya, Sri Lanka to assess their thyroid function formed the study group. Patients who were not on thyroxine or antithyroid drugs at the time of sample collection were included in the study after obtaining their informed written consent. Ethical clearance for the study was obtained from Ethics Committee, Postgraduate Institute of Science, Sri Lanka. Blood samples, $5 \mathrm{ml}$ were collected under aseptic and antiseptic conditions. The clotted blood was centrifuged at $5000 \mathrm{~g}$ for 5 minutes to separate serum. Analysis of the serum parameters were carried out on the same day except serum TSH. Serum for TSH measurement was stored at $-450 \mathrm{C}$. The height and weight were recorded with standardized instruments before the collection of blood. Test subjects were both males and females and their age ranged from 15 to 85years. Serum TSH was measured by immunoradiometric assay (IRMA) using RIA-gnost ${ }^{\circledR}$ hTSH Cisbio Bioassays kit. It permits the in vitro determination of thyrotropin in human serum or plasma by a 1-step sandwich assay. Anti- human thyrotropin (hTSH) antibodies (monoclonal, mouse), are bound directly or indirectly to the inner wall of polystyrene tubes. Oxidant stress was estimated by serum Total Antioxidant Capacity (TAC) and serum protein thiol concentration. TAC was estimated using Ferric Reducing Ability of Plasma, by reducing ferric-tripyridyltriazine $\left(\mathrm{Fe}^{3+}\right.$-TPTZ) to form a blue colored ferrous-tripyridyltriazine $\left(\mathrm{Fe}^{2+}+\right.$ TPTZ) complex..$^{10}$ Protein thiol in serum was estimated using Ellman's reagent. ${ }^{15}$ All the statistical analyses were done using Minitab 14 statistical software. For the mean comparisons 2 sample test was used and a $p$ value $<0.05$ was considered significant.

\section{Results}

The mean age of the study population $(n=93)$ was $44.7 \pm 13.8$ years with $2(2.2 \%)$ patients below 18years of age, $43(46.2 \%)$ adults aged between 18 to 45 years and $48(51.6 \%)$ above $45 y$ years of age. Their mean TSH concentration was $5.4 \pm 12.3 \mathrm{mU} / \mathrm{L}$, mean serum TAC was $719.1 \pm 164.5 \mu \mathrm{mol} / \mathrm{L}$ and mean serum Protein thiol concentration was $517.7 \pm 89.8 \mu \mathrm{mol} / \mathrm{L}$ (Table 1 ). TSH concentration showed a wide range.

Among the patients investigated $39(41.9 \%)$ had enlarged thyroid glands while others $(n=54,58.1 \%)$ did not show any thyroid enlargement. Among the patients with enlarged thyroid, majority $(\mathrm{n}=31,79.5 \%)$ had multi nodular goiter, while only $5(12.8 \%)$ had diffused enlargement and 3(7.7\%) had solitary thyroid nodules.

In the study population, based on serum TSH concentration, 9 patients $(9.7 \%)$ were hyperthyroid, $68(73.1 \%)$ were euthyroid while $16(17.2 \%)$ were hypothyroid. There was a significant positive correlation between TSH and TAC $(r=0.526, \mathrm{P}=0.036)$ in hypothyroid patients (Figures 2). No such correlation was observed in hyperthyroids or euthyroids. There were no significant differences in TAC or protein concentrations between the groups (Table 2). The probability plot for TAC in hypothyroid patients indicated a normal distribution $(\mathrm{p}=0.31)$ (Figure 3).

Majority of the study population, $85(91.4 \%)$ were females and only $8(8.6 \%)$ were males. Females had a mean TSH of $4.5 \pm 10.3 \mathrm{mU} / \mathrm{L}$, (Range $=0.10-58.00 \mathrm{mU} / \mathrm{L}$, Median $=1.90 \mathrm{mU} / \mathrm{L})$ which was not significantly different from that of males $(14.75 \pm 24.34 \mathrm{mU} / \mathrm{L})$ (Range $=0.20-58.00 \mathrm{mU} / \mathrm{L}$, Median $=2.20 \mathrm{mU} / \mathrm{L})(\mathrm{P}=0.272)$. The mean serum TAC in males $(928.7 \pm 60.4 \mu \mathrm{mol} / \mathrm{L})$ was significantly higher than that of females $(699.4 \pm 150.5 \mu \mathrm{mol} / \mathrm{L})(\mathrm{P}=0.006)$. Similarly, mean serum protein thiol concentration of males $(570.7 \pm 23.6 \mu \mathrm{mol} / \mathrm{L})$ was significantly higher than that of females $(512.7 \pm 90.0 \mu \mathrm{mol} / \mathrm{L})$ $(\mathrm{P}=0.049)$ (Table 3).

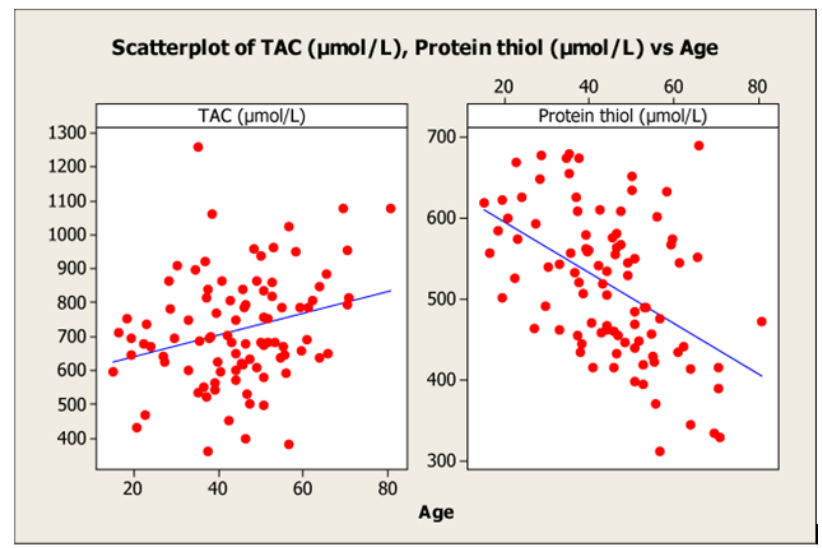

Figure I Correlation between TAC and protein Thiol with age.

Table I Mean, maximum and minimum values for Age, TSH, TAC, Protein thiol and BMI. Age had a significant positive correlation with TAC $(r=0.268$, $\mathrm{P}=0.009)$, and a significant negative correlation with protein thiol $(r=-0.48$ I, $\mathrm{P}<0.00 \mathrm{I})$ (Figure I). BMI of the patients increased significantly with age $(r=0.250, P=0.019)$

\begin{tabular}{llll}
\hline & Mean \pm SD & Minimum & Maximum \\
\hline Age $($ Years $)$ & $44.7 \pm 13.8$ & 15.1 & 80.8 \\
TSH $(\mathrm{mU} / \mathrm{L})$ & $5.4 \pm 12.3$ & 0.1 & 58.0 \\
TAC $(\mu \mathrm{mol} / \mathrm{L})$ & $719.1 \pm 164.5$ & 360.2 & 1261.0 \\
Protein thiol $(\mu \mathrm{mol} / \mathrm{L})$ & $517.7 \pm 89.5$ & 311.6 & 689.3 \\
BMI $\left(\mathrm{Kg} / \mathrm{m}^{2}\right)$ & $23.11 \pm 4.47$ & 13.8 & 35.9 \\
\hline
\end{tabular}


Table 2 Mean values for Age, TSH, TAC and Protein thiol. Superscripts in columns with same letter are not significantly different the distribution of TAC and protein thiol in hypothyroid, euthyroid and hyperthyroid patients are presented in Figures 4, Figure5.The range and SD values for TAC and protein thiol indicated a wide variation whereby mean comparison did not reveal any significant differences among the groups

\begin{tabular}{|c|c|c|c|c|c|}
\hline & & Age (Years) & TSH (mU/L) & TAC ( $\mu \mathrm{mol} / \mathrm{L})$ & Protein thiol ( $\mu \mathrm{mol} / \mathrm{L})$ \\
\hline \multirow{3}{*}{$\begin{array}{l}\text { Hyperthyroid } \\
(n=9)\end{array}$} & Mean \pm SD & $53.3 \pm 16.1^{\mathrm{a}}$ & $0.1222 \pm 0.044$ & $785.5 \pm 151.7^{b}$ & $496.5 \pm 141.5^{c}$ \\
\hline & Range & $26.90-71.00$ & $0.1000-0.2000$ & $640.5-1075.8$ & $328.1-689.3$ \\
\hline & Median & 55.7 & 0.1 & 780.3 & 483.5 \\
\hline \multirow{3}{*}{$\begin{array}{l}\text { Euthyroid } \\
(n=68)\end{array}$} & Mean \pm SD & $44.6 \pm 12.5^{\mathrm{a}}$ & $1.82 \pm 1.060$ & $706.6 \pm 167.1^{b}$ & $516.0 \pm 79.5^{c}$ \\
\hline & Range & $16.60-80.80$ & $0.400-4.000$ & $360.2-1261.0$ & $311.60-678.30$ \\
\hline & Median & 44.85 & 1.6 & 683.4 & 527.1 \\
\hline \multirow{3}{*}{$\begin{array}{l}\text { Hypothyroid } \\
(n=16)\end{array}$} & Mean $\pm S D$ & $40.0 \pm 16.3^{a}$ & $23.38 \pm 22.39$ & $734.9 \pm 159.8^{\mathrm{b}}$ & $536.8 \pm 97.4^{c}$ \\
\hline & Range & $15.10-70.60$ & $4.20-58.00$ & $430.8-955.1$ & $388.8-673.7$ \\
\hline & Median & 41.1 & 11.2 & 739.8 & 546.4 \\
\hline
\end{tabular}

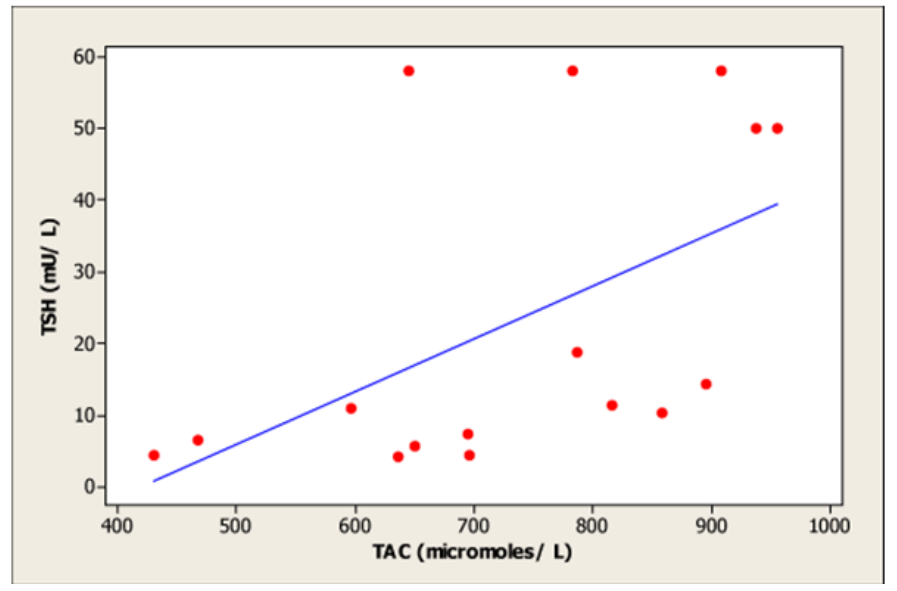

Figure 2 Correlation between TSH and TAC in hypothyroid patients.

Table 3 Mean Age, TSH, TAC and Protein thiol according to gender. Superscripts in rows with same letter are not significantly different Mean serum TAC and protein thiol concentration of females had a significant negative correlation $(r=-0.263, P=0.015)$ (Figure 4$)$. The probability plot of TAC in females indicated a normal distribution $(p=0.503)$. In contrast, no significant correlation was observed between TAC and protein thiol levels of men $(r=0487, P=0.22 \mathrm{I})$ This could be attributed to the smaller number of males in the study

\begin{tabular}{lll}
\hline & \multicolumn{2}{c}{ Mean \pm SD } \\
\cline { 2 - 3 } & Female & Male \\
\hline Age $($ Years $)$ & $44.2 \pm 13.9^{\mathrm{a}}$ & $50.00 \pm 12.76^{\mathrm{a}}$ \\
$\mathrm{TSH}(\mathrm{mU} / \mathrm{L})$ & $4.5 \pm 10.3^{\mathrm{a}}$ & $14.75 \pm 24.34^{\mathrm{a}}$ \\
$\mathrm{TAC}(\mu \mathrm{mol} / \mathrm{L})$ & $699.4 \pm 150.5^{\mathrm{a}}$ & $928.74 \pm 170.96^{\mathrm{b}}$ \\
Protein thiol $(\mu \mathrm{mol} / \mathrm{L})$ & $512.7 \pm 90.0^{\mathrm{a}}$ & $570.66 \pm 66.72^{\mathrm{b}}$ \\
\hline
\end{tabular}

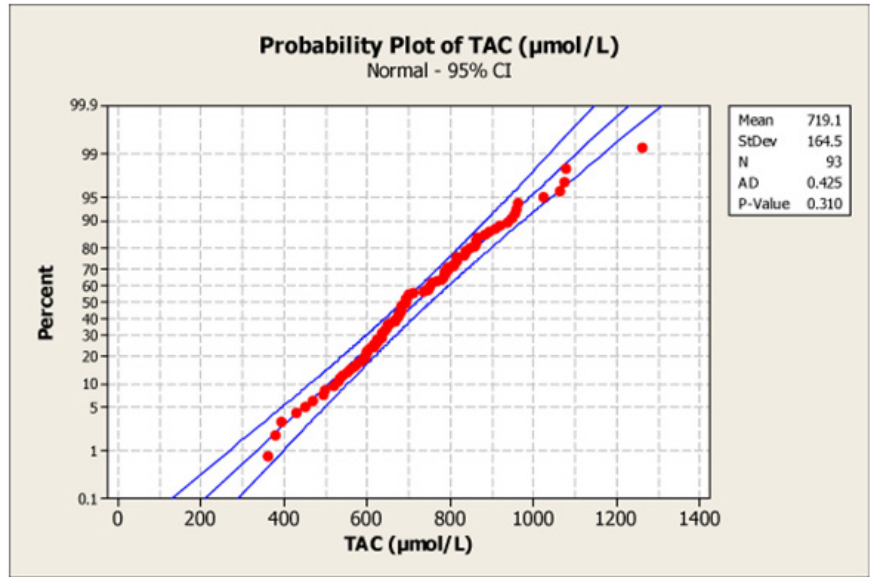

Figure 3 Probability plot for TAC in hypothyroid patients.

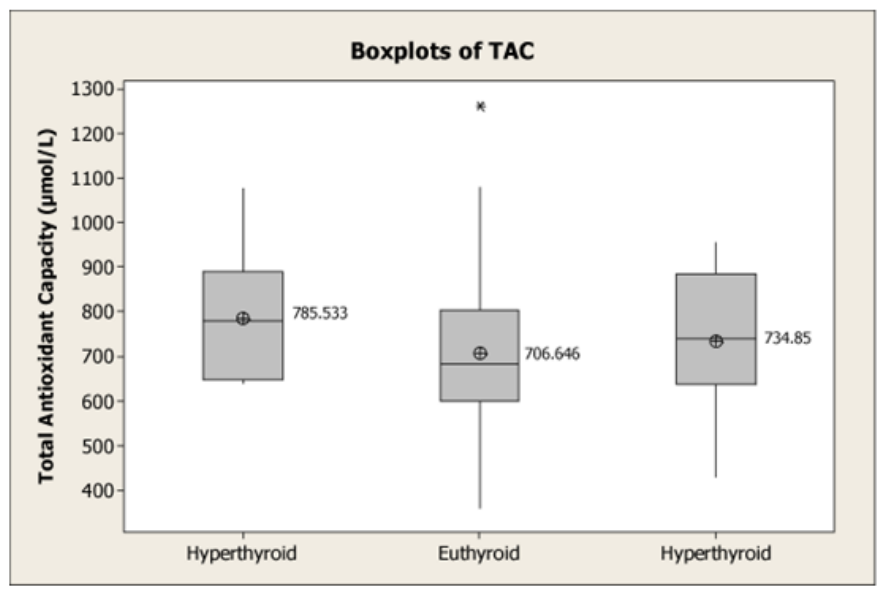

Figure 4 Distribution of TAC in hyperthyroid, Euthyroid and hypothyroid patients. 


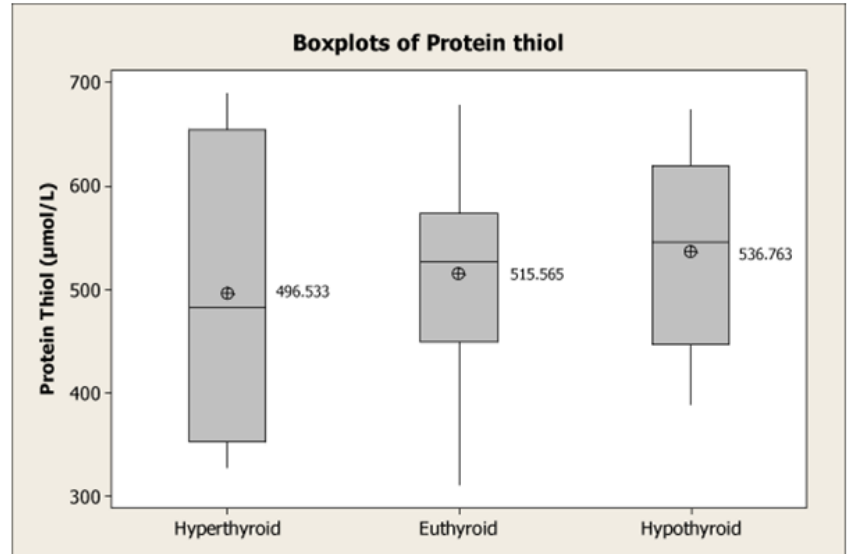

Figure 5 Distribution of protein thiol in hyperthyroid, Euthyroid and hypothyroid patients.

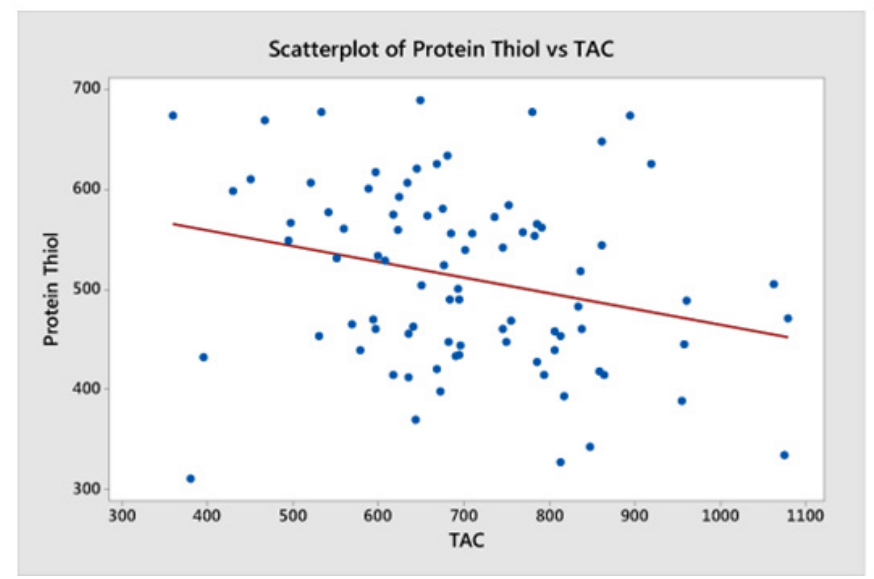

Figure 6 Correlation between TAC and protein thiol in females.

\section{Discussion}

Mean TAC concentration seen in this study $(719.1 \pm 164.5 \mu \mathrm{mol} / \mathrm{L})$ is lower than that of apparently healthy Chinese adults $(1017 \pm 206 \mu \mathrm{mol} / \mathrm{L}),{ }^{10}$ and higher than seen in plasma samples $(514.1 \pm 19.1 \mu \mathrm{mol} / \mathrm{L})$ of unselected Italian outpatients referred to the Institute of Clinical Physiology. ${ }^{16}$ Mean protein thiol concentration obtained in this study was higher than those seen in healthy controls $(376 \pm 64 \mu \mathrm{mol} / \mathrm{L})$ in India. ${ }^{17}$ Mean TAC in healthy Netherland males reported by Jansen and Ruskovska ${ }^{18}(1392 \pm 158 \mu \mathrm{mol} / \mathrm{L})$ was higher than that seen in this study. In contrast, mean protein thiol value of $431 \pm 52 \mu \mathrm{mol} / \mathrm{L}$ in Netherland males was lower than that seen in males in the present study.

There were no significant differences in TAC or protein thiol concentrations between hypothyroid, euthyroid and hyperthyroid patients in the current study. In contrast to the present study, Rao et al., ${ }^{5}$ observed in patients with thyroid dysfunction, significantly lower protein thiol concentration in hyperthyroid and hypothyroid patients compared to euthyroid controls. Joshi et al., ${ }^{19}$ too reported that TAC decreased significantly in both hyperthyroid and hypothyroid patients when compared with euthyroid subjects. Bhawna Bhimte et al., ${ }^{20}$ were also of the view that hypothyroidism results in a lowering of serum TAC concentration. Aslan ${ }^{21}$ has evaluated the oxidative status in patients with hyperthyroidism, using 36 hyperthyroid patients and 30 healthy controls. Significantly lower serum TAC concentrations in patients with hyperthyroidism than controls have been reported indicating oxidative stress. Serum TAC concentrations in patients significantly correlated with TSH concentrations positively and FT3 and FT4 concentrations negatively. In conclusion they stated that, in patients with hyperthyroidism, the oxidative-antioxidative balance is shifted to the oxidative side and the increased oxidative stress may play a role in the pathogenesis of hyperthyroidism. Studies conducted so far clearly indicated a lowering of TAC in hyperthyroidism and hypothyroidism where as the present study could not notice any significant alteration in TAC irrespective of the functional status of the thyroid.

The significant positive correlation between TSH and TAC $(\mathrm{r}=0.526, \mathrm{P}=0.036)$ in hypothyroid patients in the present study hitherto has not been reported. Serum TSH in hypothyroid patients is a measure of the extent of under activity of the thyroid gland and a higher TSH concentration means an overt hypothyroidism. Therefore it could be expected that the TAC concentration to relate positively with TSH concentration.

Both TAC and protein thiol levels were high in males than females (Table 3). Similarly, mean TAC values seen in male Italian outpatients referred to the Institute of Clinical Physiology $(535 \pm 25.6 \mu \mathrm{mol} / \mathrm{L})$ was higher than that of females $(469 \pm 22.5 \mu \mathrm{mol} / \mathrm{L})$ although not significantly different.

This study showed a significant negative correlation between TAC and protein thiol concentrations of females. The probability plot of TAC in females indicated a normal distribution. TAC is an estimate of the reducing ability of serum and not only protein thiol the other substances found in serum could also contribute to the reducing ability. In males no significant correlation between TAC and protein thiol concentration could be observed may be due to smaller numbers involved in the study. In the study done by Jansen and Ruskovska (2013), total thiols of males have shown a negative but non significant correlation with the TAC $(\mathrm{r}=-0.008)$.

\section{Conclusion}

Mean TSH of study group was just above the normal reference level indicating mild thyroid insufficiency. A significant positive correlation was observed between TSH and TAC in hyperthyroid patients. No significant differences in TAC and protein thiol concentration were evident among euthyroid, hyperthyroid and hypothyroid patients. The mean TAC and protein thiol in males were significantly higher than those of females. Based on serum TAC and protein thiol concentrations it could be concluded that the antioxidant status had not been significantly altered among the different groups patients.

\section{Acknowledgements}

None.

\section{Conflict of interest}

The author declares no conflict of interest.

\section{References}

1. Tao Y, Gu H, Wu J, et al. Thyroid function is associated with non-alcoholic fatty liver disease in euthyroid subjects. Endocr Res. 2014;20:1-5.

2. Zhao W, Han C, Shi X, et al. Prevalence of Goiter and Thyroid Nodules before and after implementation of the Universal Salt Iodization Program in Mainland China from 1985 to 2014:A Systematic Review and MetaAnalysis. PLoS ONE. 2014;9(10):e109549. 
3. Dave A, Maru L, Tripathi M. Importance of Universal screening for thyroid disorders in first trimester of pregnancy. Indian $J$ of Endocrinol Metab. 2014;18(5):735-738.

4. Abalovich M, Liesuy S, Gutierrez S, et al. Peripheral parameters of oxidative stress in Graves's disease: The effect of methimazole and 131 iodine treatment. Clin Endocrinol. 2003;59(3):321-327.

5. Namita Rao, Prasad Anushre. Erythrocyte glutathione system and plasma protein oxidation in thyroid dysfunction. Pharmacie Globale: International Journal of Comprehensive Pharmacy. 2012;3(1).

6. Mirela P, Adriana M, Ileana D. Oxidative stress and antioxidant status in hypo- and hyperthyroidism; 2013.

7. Carlos K, Bucalen F. Total Antioxidant Capacity: a biomarker in biomedical and nutritional studies. Journal of Cell and Molecular Biology. 2008;7(1):1-15

8. Carolina MC, Rita CCDS, Emerson SL. A simple automated procedure for thiol measurement in human serum samples. J Bras Patol Med Lab. 2006;42(5):345-350.

9. Andryskowski G, Owczarek T. The evaluation of selected oxidative stress parameters in patients with hyperthyroidism. Pol Arch Med Wewn. 2007;117(7):285-289.

10. Benzie IF, Strain JJ. The ferric reducing ability of plasma (FRAP) as a measure of "antioxidant power": the FRAP assay. Anal Biochem. 1996;239(1):70-76.

11. Mahadeva K, Senthe Shanmuganathan S. The problem of goitre in Ceylon. Br J Nutr. 1967;21(2):341-352.

12. Fernando MA, Balasuriya S, Herath $\mathrm{KB}$, et al. Endemic goitre in Sri Lanka. Asia Pac JPublic Health. 1989;3(1):11-18
13. Premawardhana LD, Parkes AB, Smyth PP, et al. Increased prevalence of thyroglobulin antibodies in Sri Lankan schoolgirls-is iodine the cause? Eur J Endocrinol. 2010;143(2):185-188.

14. Smyth PP, Wijeyaratne CN, Kaluarachi WN, et al. Sequential studies on thyroid antibodies during pregnancy. Thyroid. 2005;15(5):474-477.

15. Koster JF, Biemond P, Swaak AJG. Intracellular and extracellular sulphydryl levels in rheumatoid arthritis. Annals of the Rheumatic Diseases. 1986;45(1):44-46.

16. Vassalle C, Masini S, Carpeggiani C, et al. In vivo total antioxidant capacity: comparison of two different analytical methods. Clin Chem Lab Med. 2004;42(1):84-89.

17. Suresh B, Shetty JK, Prakash M. Cardiac enzymes, total thiols and lipid peroxidation in patients with acute myocardial infarction. Journal of Clinical and Diagnostic Research. 2010;4(6):3425-3429.

18. Jansen EHJM, Ruskovska T. Comparative analysis of serum (anti) oxidative status parameters in healthy persons. Int J Mol Sci. 2013;14(3):61066115.

19. Joshi B, Jabannavar VB, Malleshappa A, et al. Estimation of the levels of lipid peroxidation and total antioxidant capacity in hyperthyroid, hypothyroid \& euthyroid subjects-A crosssectional study. International journal of pharmacology and therapeutics. 2014;4(2):1-7.

20. Bhawna Bhimte, Agrawal BK, Sharma VK, et al. Oxidative stress status in hypothyroid patients. Biomedical Research. 2012;23(2):286-288.

21. Aslan M, Cosar N, Celik H, et al. Evaluation of oxidative status in patients with hyperthyroidism. Endocrine. 2011;40(2):285-289. 